\title{
ANALISIS BAHASA RAKYAT MASYARAKAT PESISIR
}

\author{
Amnur Rifai Dewirsyah \\ Universitas Muhammadiyah Sumatera Utara \\ 140279rifai@gmail.com
}

\begin{abstract}
ABSTRAK
Penelitian ini bertujuan untuk mengetahui sistem sapaan yang digunakan oleh penutur bahasa Melayu Asahan pada zaman dahulu dan sekarang dan pertimbangan penggunaan kata sapaan yang digunakan dahulu dan sekarang, serta faktor yang mempengaruhi terjadinya perubahan sistem sapaan tersebut. Penelitian ini menggunakan metode deskriptif kualitatif. Data yang dikumpulkan melalui teknik wawancara dan observasi. Dari hasil wawancara terhadap 6 orang informan (4 orang informan berusia 75 -110 tahun, dan 2 informan berusia 20-45 tahun) dan hasil observasi, peneliti menemukan ada banyak variasi kata sapaan yang digunakan oleh para penutur bahasa Melayu Asahan dahulu dan sekarang. Pilihan kata sapaan yang digunakan untuk menyapa kekerabatan berdasarkan garis keturunan dan garis perkawinan. Masyarakat Asahan khususnya di kecamatan Teluk Nibung menganut garis keturunan patrilineal atau garis keturunan ayah. Maka dari faktor tersebut yang menjadi kerabat ayah keluarga ayah, pada masa lalu kata sapaan bisa digunakan untuk melihat tingkatan seseorang dalam keluarga. Sedangkan pada masa sekarang kata sapaan yang digunakan sebagiannya tidak bisa lagi digunakan untuk melihat tingkatan seseorang dalam keluarga. Adapun faktor yang memperngaruhi perubahan penggunaan kata sapaan tersebut adalah adanya faktor gengsi (mengganggap kata sapaan dari bahasa lain lebih bernilai dan modern), pernikahan campuran. Pada akhirnya jika perubahan ini terus terjadi maka bisa saja pada masa yang akan datang orang Melayu Asahan asli tidak akan mengenal sistem sapaan yang ada dalam bahasa Melayu Asahan
\end{abstract}

Kata kunci: Bahasa rakyat, sistem sapaan, kekerabatan, Asahan

\section{PENDAHULUAN}

\author{
Pembinaan, pengembangan, \\ dan pemeliharaan bahasa daerah \\ dalam menunjang pertumbuhan dan
} perkembangan bahasa dan kebudayaan nasional, secara tegas dicantumkan dalam penjelasan pasal 36 UUD 1945. Daerah-daerah yang mempunyai bahasa sendiri yang 
dipelihara oleh rakyatnya dengan baik-baik, misalnya bahasa Jawa, Sunda, dan Madura itu akan dihormati dan dipelihara oleh negara. Peranan bahasa daerah semakin penting mengingat bahasa-bahasa daerah merupakan kekayaan budaya yang harus dimanfaatkan untuk kepentingan pembinaan dan pengembangan bahasa daerah itu sendiri serta pembinaan, pengembangan, dan pemerkayaan bahasa nasional.

Yang termasuk dalam folklor adalah bahasa rakyat adalah bahasa yang dijadikan sebagai alat komunikasi diantara rakyat dalam suatu masyarakat atau bahasa yang dijadikan sebagai sarana pergaulan dalam hidup sehari-hari. Seperti : logat (dialect), slang, cant (argot), bahasa para pedagang (shop talk), colloquial, sirkumlokusi, pemberian nama, pemberian julukan, kata sapaan, penukaran nama, gelar kebangsawanan, bahasa bertingkat, onomatopoetis, onomastis.
Kata sapaan itu berupa kata-kata yang digunakan untuk menyapa, menegur, menyebut, orang kedua, atau orang yang diajak berbicara. Chaer (2000:107) menyatakan bahwa kata sapaan adalah kata-kata yang dipergunakan untuk menyapa, menegur, atau menyebut orang kedua, atau orang yang diajak bicara.

Tujuan Penelitian apabila seseorang melakukan sebuah penelitian pasti ada tujuan tertentu agar kegiatan penelitian yang dilakukan itu menjadi lebih terarah dan dapat dilaksanakan dengan lebih efektif dan efesien. Oleh sebab itu, tujuan penelitian ini adalah sebagai berikut: 1.Bagaimana penggunaan kata sapaan kekerabatan berdasarkan garis keturunan pada masyarakat Kabupaten Asahandi Kecamatan Teluk Nibung. 2. Bagaimana penggunaan kata sapaan kekerabatan berdasarkan garis perkawinan pada masyarakat Kabupaten Asahan di Kecamatan Teluk Nibung. 3. Bagaimana penggunaan kata sapaan kekerabatan berdasarkan garis keturunan dan perkawinan pada 
masyarakat Kabupaten Asahan di Kecamatan Teluk Nibung.

Menurut Kridalaksana dalam martini (2004: 6) satuan bahasa mempunyai sistem tutur sapa, yakni sistem yang mempertautkan seperangkat kata-kata atau ungkapan-ungkapan yang dipakai untuk menyebut dan memanggil para pelaku dalam suatu peristiwa bahasa. Oleh karena itu, sapaan merupakan salah satu cara penyampaian maksud dari yang menyapa kepada yang disapa, baik secara lisan maupun tulisan dalam bentuk perangkat katakata. Tutur sapa sebagai suatu sistem untuk menyampaikan maksud, mempunyai peranan penting karena sistem penyapa yang berlaku dalam bahasa-bahasa tertentu berbeda dengan sistem penyapa yang berlaku dalam bahasa yang lain. Perbedaan itu tidak hanya terletak pada kosakata sapaan, tetapi juga pada sikap penuturnya ketika proses sapaan berlangsung.

Bentuk sapaan dalam bahasa Melayu Asahanhampir mirip dengan bahasa Melayu lainnya, misalnya bentuk sapaan. Bentuk sapaan pada bahasa melayu Asahandi tentukan oleh beberapa faktor, yaitu jenis kelamin, usia, status, ikatan kekerabatan, situasi pembicaraan, serta urutan kelahiran. Pemakaiaan tersebut didasarkan pada konvensi yang berlaku dalam masyarakat Melayu Asahan. Sehubungan dengan hal itu, bahasa Melayu Asahan mengenal dan memakai seperangkat bentuk penyapa yang disesuaikan dengan beberapa hal, yaitu: 1. Jenis kelamin pembicara dan kawan bicara, 2. Status dan kedudukan pembicara dan kawan bicara, 3. Usia pembicara dan kawan bicara, 4. Ikatan kekeluargaan, 5. Situasi pembicaraan atau keakraban, 6. Urutan kelahiran

Keluarga inti adalah keluarga yang terdiri atas ayah, ibu, dan anak ;sedangkan keluarga luas mencakup hubungan keluarga pihak ayah dan ibu mula dari urutan tertua sampai yang termuda. Mulai dari kakek atau nenek piyut, kakek atau nenek piyut, 
kakek dan nenek, ayah, ibu, paman, bibi, cucu, dan cicit.

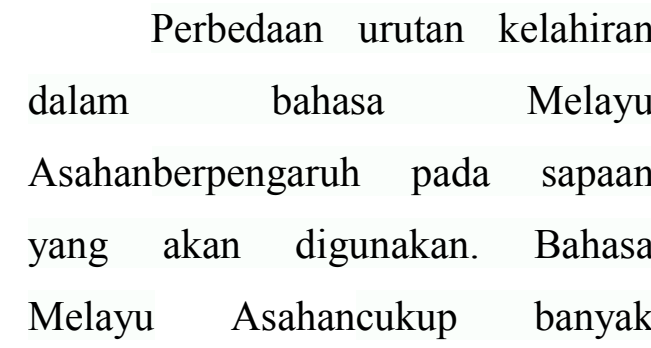
memiliki istilah untuk penyapa anak berdasarkan urutan kelahiran. Sapaan berdasarkan urutan kelahiran dalam bahasa Melayu Asahan tidak berbeda jauh dengan sapaan daerah lain. Apabila sebuah keluarga hanya memiliki dua anak maka anak pertama akan disapaan dengan sapaan Ulong dan anak kedua akan disapaan dengan sapaan Ucu. Lain halnya apabila dalam sebuah keluarga ada tiga orang anak, yang pertama disapa Along atau Ulong, yang kedua Ongah, dan yang ketiga Usu atau Ucu. Jika dalam keluarga anaknya lebih dari tiga tetap saja untuk panggilan atau sapaan anak pertama Along atau Ulong, semua yang berada di urutan disapa berdasarkan urutan lahir dan sapaan Usu atau Ucu sapaan untuk anak bungsu.
Kota Asahan adalah salah satu kota di provinsi Sumatra Utara. Luas wilayahnya 62,98 km. Entis Melayu dan Batak yang sebagaian besarnya beragama islam. Disamping etnis tersebut, terdapat juga beberapa etnis lainnya seperti: Jawa, Tionghoa, Minang dan India. Namun, etnis Melayu merupakan motor utama penggerak roda kebudayaan di Asahan. Oleh sebab itu, semua sistem kebudayaan menganut suku melayu. Orang Batak merupakan etnis kedua yang menempati posisi penting setelah etnis melayu, baik dari segi partisipasi pembangunan daerah maupun kebudayaan. Karena banyaknya etnis ini di Asahan, maka ada kesan bahwa Melayu Asahanmerupakan orang Batak yang berkhitan istilah berkhitan disebut juga dengan "masuk Melayu”

\section{METODOLOGI PENELITIAN}

Penelitian ini menggunakan pendekatan kualitatif dengan metode deskriptif. (Moleong, 2005:4) menyatakan bahwa metodologi kualitatif sebagai prosedur penelitian 
yang menghasilkan data deskriptif berupa kata-kata tertulis atau lisan dari orang-orang dan prilaku yang dapat diamati. Jenis dan metode ini tepat digunakan dalam penelitian ini karena data penelitian bersumber dari data lisan yakni bentuk sapaan masyarakat Tanjungbalai Kecamatan Teluk Nibung. Data dalam penelitian ini adalah tuturan dalam bentuk kalimat yang di dalamya terdapat kata sapaan yang digunakan oleh masyarakat Tanjungbalai Kecamatan Teluk Nibung Kabupaten Asahan ditinjau dari kata sapaan kekerabatan berdasarkan keturunan dan berdasarkan perkawinan.

Didasarkan pada ciri-ciri keilmuan yaitu rasional, empiris, dan sistematis. Jenis metode penelitian ini adalah deskriptif kualitatif. Data dari penelitian ini adalah semua jenis kata sapaan yang digunakan dalam bahasa Melayu Tanjungbalai. Peneliti, menggunakan sumber data lisan (sumber data hasil wawancara dengan penutur bahasa Melayu Asahandan obsevasi). Dalam penelitian ini, peneliti mengunakan teknik purposive sampling dengan jumlah partisipan sebanyak 6 orang. Kriteria pemilihan partisipan dalam penelitian ini berdasarkan tingkat usia dan kemampuannya dalam berbahasa Melayu Asahan Usia informan dalam penelitian ini adalah antara 20 tahun- 100 tahun.

\section{HASIL PENELITIAN DAN PEMBAHASAN}

Berdasarkan data penelitian ini, kata sapaan kekerabatan berdasarkan garis keturunan ditinjau dari bentuk dan pemakaian sebagai berikut ini:

\begin{tabular}{|c|c|c|c|c|}
\hline NO & $\begin{array}{l}\text { Penggunaan } \\
\text { Kata Sapaan }\end{array}$ & $\begin{array}{ll}\text { Bentuk Kata } \\
\text { Sapaan }\end{array}$ & $\begin{array}{l}\text { Contoh } \\
\text { Tuturan }\end{array}$ & Keterangan \\
\hline 1 & Ayah kandung & Ayah & $\begin{array}{l}\text { Tanggal lahir } \\
\text { ayah berapo? }\end{array}$ & $\begin{array}{l}\text { Tuturan terjadi ketika } \\
\text { ego menanyakan } \\
\text { kepada ayah kapan } \\
\text { tanggal lahir beliau. }\end{array}$ \\
\hline
\end{tabular}




\begin{tabular}{|c|c|c|c|c|}
\hline 2 & $\begin{array}{l}\text { Kakak laki- } \\
\text { laki ayah }\end{array}$ & Uwak & $\begin{array}{lr}\text { Kalo } & \text { samo } \\
\text { Uwak } & \text { iye } \\
\text { berapo? } & \end{array}$ & $\begin{array}{l}\text { Tuturan terjadi ketika } \\
\text { ego menanyakan } \\
\text { berapa harga } \\
\text { dagangan yang dijual } \\
\text { paman iye }\end{array}$ \\
\hline 3 & $\begin{array}{l}\text { Adik laki-laki } \\
\text { ayah }\end{array}$ & Bapak, pak cik & $\begin{array}{l}\text { Pak cik ondak } \\
\text { kemano? }\end{array}$ & $\begin{array}{l}\text { Tuturan terjadi ketika } \\
\text { ego menanyakan mau } \\
\text { kemana paman. }\end{array}$ \\
\hline 4 & $\begin{array}{l}\text { Kakak } \\
\text { perempuan } \\
\text { ayah }\end{array}$ & Uwak & $\begin{array}{l}\text { Moh kita pogi } \\
\text { wak }\end{array}$ & $\begin{array}{l}\text { Tuturan terjadi ketika } \\
\text { ego mengajak pergi } \\
\text { bibinya. }\end{array}$ \\
\hline 5 & $\begin{array}{l}\text { Adik } \\
\text { perempuan } \\
\text { ayah }\end{array}$ & Unde & $\begin{array}{l}\text { Dimano buang } \\
\text { nde? }\end{array}$ & $\begin{array}{lr}\text { Tuturan } & \text { terjadi ketika } \\
\text { ego } & \text { menanyakan } \\
\text { dimana } & \text { buang } \\
\text { sampah. } & \end{array}$ \\
\hline 6 & $\begin{array}{l}\text { Kakak laki- } \\
\text { laki }\end{array}$ & Ulong, Abah & $\begin{array}{l}\text { Oh long buatkan } \\
\text { dulu omak teh. }\end{array}$ & $\begin{array}{l}\text { Tuturan terjadi ketika } \\
\text { ego meminta } \\
\text { dibuatkan teh. }\end{array}$ \\
\hline 7 & $\begin{array}{l}\text { Kakak } \\
\text { perempuan }\end{array}$ & Kakak, uteh & $\begin{array}{l}\text { Susi koh ado } \\
\text { tampok } \\
\text { Uteh } \\
\text { yuni tak? }\end{array}$ & $\begin{array}{l}\text { Tuturan terjadi ketika } \\
\text { ego menanyakan ada } \\
\text { melihat kakak yuni. }\end{array}$ \\
\hline 8 & Adik laki-laki & $\begin{array}{l}\text { Panggil nama, } \\
\text { adik }\end{array}$ & $\begin{array}{l}\mathrm{Ku} \text { lotuplah koh } \\
\text { Andi }\end{array}$ & $\begin{array}{l}\text { Tuturan terjadi ketika } \\
\text { ego marah dan ingin } \\
\text { memukul adiknya. }\end{array}$ \\
\hline 9 & $\begin{array}{l}\text { Adik } \\
\text { perempuan }\end{array}$ & $\begin{array}{l}\text { Panggil nama, } \\
\text { adik }\end{array}$ & $\begin{array}{l}\text { Pinomat koh } \\
\text { sapu itu kojap } \\
\text { yeni. }\end{array}$ & $\begin{array}{l}\text { Tuturan terjadi ketika } \\
\text { ego meminta adiknya } \\
\text { untuk menyapu. }\end{array}$ \\
\hline 10 & Anak & $\begin{array}{l}\text { Panggil nama, } \\
\text { urutan }\end{array}$ & $\begin{array}{l}\text { Apa kabanyo si } \\
\text { andak ngah? }\end{array}$ & $\begin{array}{l}\text { Tuturan terjadi ketika } \\
\text { ego menanyakan }\end{array}$ \\
\hline
\end{tabular}




\begin{tabular}{|l|l|l|l|l|}
\hline & & kelahitan & & $\begin{array}{l}\text { kabar adik kepada } \\
\text { kakak nomor 2 }\end{array}$ \\
\hline 11 & Cucu & Panggil nama & $\begin{array}{l}\text { Moh koh oncop } \\
\text { ubat koh itu } \\
\text { Andi. }\end{array}$ & $\begin{array}{l}\text { Tuturan terjadi ketika } \\
\text { ego meminta cucunya } \\
\text { untuk menelan } \\
\text { obatnya. }\end{array}$ \\
\hline 12 & Ayah dari ayah & Atok & $\begin{array}{l}\text { Atok apo } \\
\text { kabanyo? }\end{array}$ & $\begin{array}{l}\text { Tuturan terjadi ketika } \\
\text { ego menanyakan } \\
\text { kabar kakek. }\end{array}$ \\
\hline
\end{tabular}

\section{A. Analisis Sistem Sapaan}

Berdasarkan Garis Keturunan dan Pekawinan Pada Masyarakat Asahan

Kata sapaan kekerabatan berdasarkan keturunan merupakan kata sapaan yang digunakan untuk menyapa orang yang mempunyai hubungan darah. Bentuk kata sapaan kekerabatan berdasarkan keturunan dalam bahasa Melayu di Asahanpenggunaanya ditentukan oleh keturunan patrilineal atau menurut garis keturunan ayah. Berdasarkan hasil penelitian kata sapaan menurut ayah di Asahan Kecamatan Teluk Nibung di temukan tujuh belas kata sapaan. Adapun kata sapaan tersebut adalah Ayah, Atok, Onyang, Piyut,
Nenek, Uwak, Bapak, Unde, Pak cik, Kakak, Uteh, Ulong, Ongah, Alang.Namun, bentuk kata sapaan tersebut pemakaiaannya digunakan terhadap ego yang berbeda dalam kerabat berdasarkan garis keturunan.

\section{Sapaan Keluarga Inti}

Keluarga inti adalah keluarga yang terdiri atas ayah, ibu, dan anak. Sapaan yang dipakai untuk menyapa Bapak dengan sapaan Ayah, ibu dengan sapaan Omak dan menyapa anak dengan nama diri saja atau menyebut urutan kelahiran. Sapaan untuk yang paling tua Ulong, anak kedua Ongah, anak ketiga Alang, anak keempat Uteh, anak kelima Anggah, anak keenam Iyong, anak ketujuh Andak, anak kedelapan 
Uncu. Jika dalam suatu keluarga memiliki jumlah anak lebih dari delapan maka anak yang kesembilan dan kesepuluh sapaanya kembali pada sapaan yang pertama.

\section{BAGAN I}

\section{HUBUNGAN KELUARGA INTI}

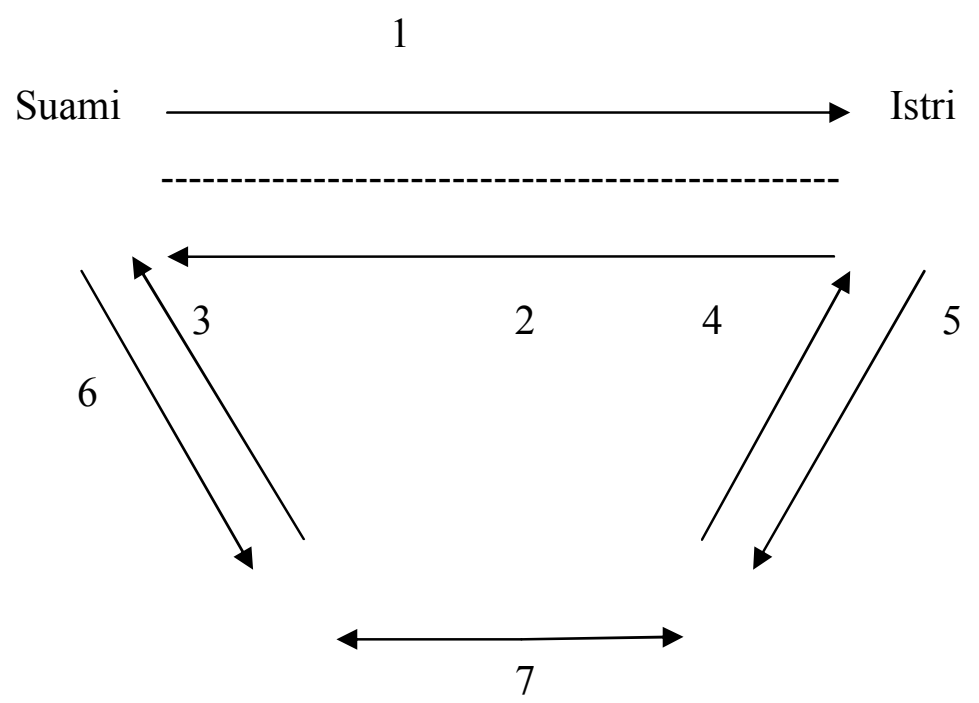

Keterangan :

1. Omak atau adek, 2. Ayah atau bungsu Uncu atau Ocik. Khusus abang, 3. Yah atau bang, 4. Omak, 5. Nak, nama. diri saja, atau menyebut urutan kelahiran, 6. Nak, nama diri saja, atau menyebut urutan kelahiran, 7. Sapaan untuk yang paling tua Ulong, untuk yang lebih muda/tengah disapa Ongah, sedangkan untuk sapaan anak sapaan anak tunggal adalah Alang.

------------ Menikah atau perkawinan Menurunkan atau menghasilkan

Saling menyapa

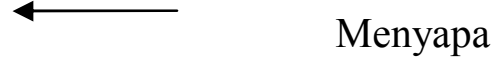

1. Ulong 
Sapaan anak pertama atau sulung disingkat menjadi Ulong sapaan ini digunakan oleh seorang adik ketika menyapa abang atau kakaknya. Sapaan ini juga digunakan oleh orang tua mereka yaitu Ayah atau Omak untuk menyapa anak petamanya sehingga sapaan itu menjadi Kak long atau Bang long. Lain halnya apabila yang akan disapa sudah dewasa dan kawan bicaranya adalah bibi atau paman atau orang yang dianggap sebagai bibi tau paman, pembicara dapat menyapanya dengan Pak long atau Mak long sehingga akan terdengar lebih akrab dan kekeluargaan. Berikut ini contoh pemakaian sapaan Ulong dalam kalimat.

(1) Ulong Jamil udah dua anaknyo.

" Abang Jamil udah dua anaknya."

(2) Romah Pak Long Udin porakporando karno angin koncang tadi
“ Rumah paman Udin (anak pertama) porakporando karno angin koncang tadi”

\section{Ongah}

Ongah merupakan kependekan dari tengah yang artinya anak tengah. Sapaan digunakan untuk menyapa anak yang berada di urutan kedua, yang terpenting sapaan Ongah itu terletak antara nomor satu dan terakhir. Sapaan Ongah dalam penggunaan sehari-hari disingkat menjadi Ngah. Berikut contohcontoh pemakaian dalam kalimat.

(1) Simpan dulu jang duet Ngah sitiin

"Simpan dulu aja uang kak siti ini."

(2) Ondak kemano Ngah?

"Mau kemana kak (anak kedua)?

$$
\text { Ayah }+
$$

$\mathrm{Ibu}$ 


\section{Ulong}

Uncu

Bagan II : Keluarga dengan jumlah anak dua orang

Keterangan:

1. $=$ menurunkan

2. $\longrightarrow$ = sapaan

3. Jumlah anak dua orang

\section{Alang}

Urutan anak ketiga dalam bahasa

Melayu Tanjungbalai disapa Alang sapaan ini digunakan untuk anak yang mempunyai kulit berwarna kuning langsat dan pada umumnya sapaan ini di peruntukan bagi anak urutan tengah. Berikut contohcontoh pemakaiannya dalam kalimat.
(1) Usah lupo 'nutupe' tingkap kamar atas yo Bang Lang! "Jangan lupa menutup jendela kamar atas, ya Bang!"

(2) Alang Lina taon depannyo masok kuliah jang.

"Kak lina tahun depanya masuk kuliah.

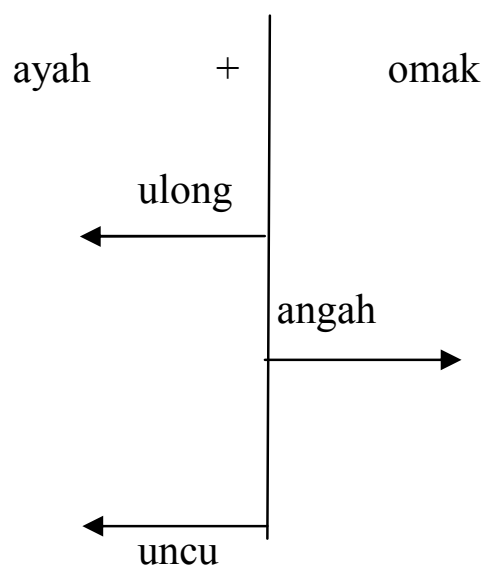


Bagan III: Keluarga dengan jumlah anak tiga orang

\section{Uteh}

Sapaan untuk anak keempat juga ada sebutan dalam bahasa Melayu Tanjungbalai. Sapaan untuk anak keempat itu ialah Uteh sapaan ini digunakan karena yang bersangkutan mempunyai kulit berwarna putih. Misalnya dalam kalimat sebagai berikut.
(1) Uteh Jaja dengan Uteh Munir bekawanyo dari orang die maseh SD.

"Jaja (anak keempat) dan Munir (anak keempat) berteman sejak mereka masih SD."

(2) Uteh Andi te malar malas belajar yo.

"Kak Andi ( anak keempat) sering malas belajar ya.

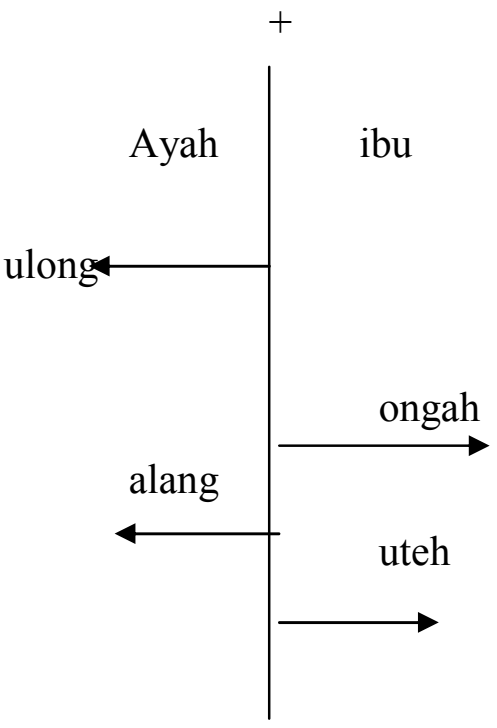

BaganIV : Keluarga dengan jumlah anak empat orang

\section{Anggah}

Sapaan untuk anak kelima juga ada sebutan dalam bahasa Melayu Tanjungbalai. Sapaan untuk 
anak kelima itu ialah Anggah sapaan ini digunakan jika sebuah keluarga memiliki anak lebih dari lima. Misalnya dalam kalimat sebagai berikut.

(1) Ngah Santi bolikan dulu omak ubat sakit kepalo.

"Kak santi (anak kelima) belikan dulu ibu obat sakit kepala."

(2) Bang Ngah ako balek la' yo.

"Bang aku pulang lah ya."

\section{Iyong}

Sapaan untuk anak keenam juga ada sebutan dalam bahasa
Melayu Tanjungbalai. Sapaan untuk anak keenam itu ialah Iyong sapaan ini digunakan jika sebuah keluarga memiliki anak lebih dari enam. Misalnya dalam kalimat sebagai berikut.

(1) Keluarganyo Nek Yong banyak tinggal ranto.

"keluarganya nenek (anak keenam) banyak tinggal di ranto."

(2) Iyong Ria sangat baek hatinyo.

"Ria (anak keenam) sangat baik hatinya."

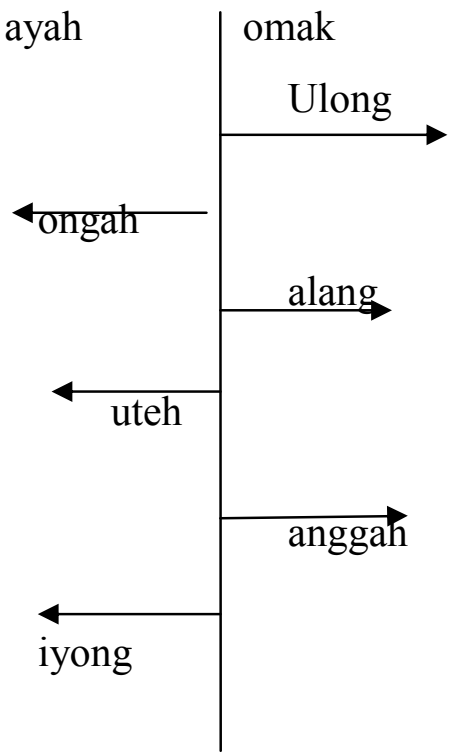

Bagan V: Keluarga dengan jumlah anak enam orang 
7. Andak

Sapaan untuk anak ketujuh juga ada sebutan dalam bahasa Melayu Asahan . Sapaan untuk anak ketujuh itu ialah Andaksapaan ini digunakan jika sebuah keluarga memiliki anak lebih dari tujuh. Misalnya dalam kalimat sebagai berikut.
(1) Wak Ndak Uci udah tibo dari tadi.

“ Wak Uci (anak ketujuh) udah tiba dari tadi."

(2) Pak Ndak jomput piyut di stasiun.

"pak Andak (anak ketujuh) jemput piyut di stasiun."

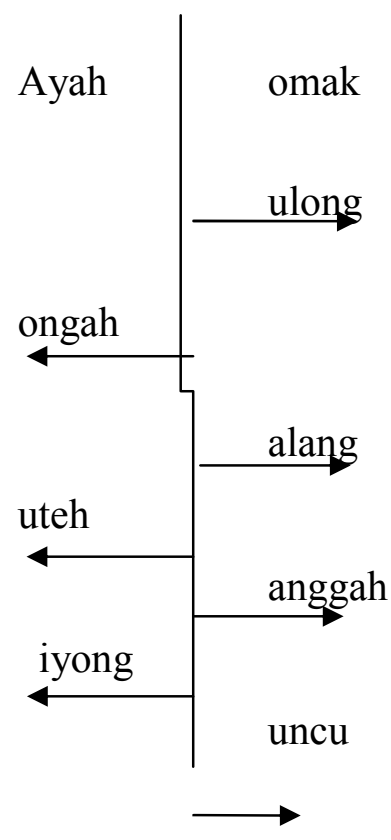

Bagan VI: Keluarga dengan jumlah anak tujuh orang 


\section{SIMPULAN}

Berdasarkan hasil penelitian bentuk kata sapaan berdasarkan keturunan patrilineal di Kecamatan Teluk Nibung Kelurahan Pematang pasir Kabupaten Asahan adalah Ayah, Apak, Uwak, Bapak, Pak Cik, Uwak, Unde, Abah, Ulong, Ongah, Alang, Uteh, Anggah, Iyong, Andak, Ucu, Kakak, Adik, Panggil nama, Atok, Onyang, Piyut. Selanjutnya, kata sapaan dalam kekerabatan berdasarkan garis perkawinan di Teluk Nibung Kabupaten Asahan adalah Omak, Uning, Apak, Nenek, Atok, Incek, Incik, Uwak, Mak Cik, Bapak, Unde, Uwak, Uwak, Andak, adik Ipar, Abang, Adik, Panggil Nama, Mamanya si Polan, Abang, Ulong, Ongah, Alang, Uteh, Anggah, Iyong, Andak, Ucu. Namun, bentuk kata sapaan tersebut pemakaiannya digunakan terhadap ego yang berbeda dalam kerabat berdasarkan perkawinan atau kerabat berdasarkan keturunan.

\section{DAFTAR PUSTAKA}

Arikunto, Suharsimi. 2009. Metode Penelitian Kualitatif dan Kuantitatif. Jakarta: Halaman Moeka Publishing. Alwi, Hasan dkk. 2005. Kamus Besar Bahasa Indonesia. Jakarta: Balai Pustaka

Chaer, Abdul. 2000. Tata Bahasa Praktis Bahasa Indonesia. Jakarta:Bharata Karya Aksara.

Chaer, Agustina. 2010. Sosiolinguistik Perkenalan Awal. Jakarta: Rineka Cipta.

Departemen Pendidikan Nasional. 2014. Kamus Besar Bahasa Indonesia Edisi Keempat. Jakarta: Balai Pustaka.

Danandjaja, James. 1994. Folklor Indonesia : Ilmu Gosip, Dongeng, dan Lainlain.Jakarta : Pustaka Utama Grafiti.

Emzir. 2015. Metodologi Penelitian Pendidikan: Kualitatif dan 
Kuantitatif. Jakarta : Marpaung. Watni 2011. Mutiara Rajawali Pers. Kota Kerang Tanjungbalai Asahan.(

Martina, Irmayani. 2004. Sistem Sapaan Bahasa Melayu Ketapang.Jakarta: Pusat Bahasa Medan : Badan Perpustakaan, Arsip dan Dokumentasi).

Nasution. M. Jasmin 1994. Sistem Sapaan Dialek Jakarta.( Jakarta : Pusat Pembinaan dan Pengembangan Nazir. $1988 . \quad$ Metode Penelitian.Jakarta : Ghalia Indonesia Bahasa).

Nasution. M. Jasmin. Dkk. 1994.

Sistem sapaan dialek Jakarta.

Jakarta: Pusat Pembinaan dan

Pengembangan Bahasa. 